\title{
PERSISTENT TRUNCUS ARTERIOSUS IN TWO SIBLINGS
}

\author{
BY \\ J. E. GOODYEAR \\ From the Hull Royal Infirmary, Hull \\ Recieved September 6, 1960
}

Congenital malformations, especially those of the heart, are among the important causes of death in the neonatal period and in childhood. The factors of heredity and environment have been discussed by numerous workers, and there are many reports about the incidence of congenital cardiac defects in one or both of twins and of more than one case of congenital cardiac disease occurring in the same family.

Medvei and Rösler (1932) reviewed 37 cases of familial cardiac lesions and Courter et al. (1948) found 63 reports describing the occurrence of congenital heart disease in two members of a family. In 1958 Carleton et al. collected the reports of 141 affected families published since 1941 and added three cases of their own. Many authors have contributed cases including Ellis (1933), Lucksch and Stohr (1936), Kjaergaard (1946), Elshove (1951) and Bertoye et al. (1952).

A number of workers have expressed their opinions on the importance of the environmental factor and on the problems of heredity. Maternal rubella during the first trimester of pregnancy appears to be the only proved environmental factor of much importance, for example Murphy (1947) collected 295 reports of congenital defects occurring after maternal rubella, including 117 malformations of the heart. The study of uniovular and biovular twins by Lamy et al. (1946) and Uchida and Rowe (1957), where in the majority of cases only one twin was affected, shows that heredity does not play a particularly important place in the production of congenital cardiac defects. Campbell (1959) reported 40 families with two or more cases of congenital heart disease and was impressed by the fact that the affected members of a family usually had the same type of malformation: he thought genetic factors the more important, probably not always decisive alone but becoming manifest under the influence of some environmental factor.

An annotation in the British Medical Journal (1959) considers that, though suggestive, multiple familial occurrences does not prove that the defects have a genetic basis, as a whole family may be exposed to some particular environmental risk. The weight of evidence appears to favour both genetic and environmental factors as having some part in the ætiology of congenital heart disease. Foxon (1959) concluded that it would be reasonable to suppose that there is more than one cause of congenital heart disease, and mentioned the interventricular septum that may be underdeveloped due to nutritional deficiency, or well developed but incorrectly aligned, and therefore incomplete, due to some genetic factor.

The object of this paper is to present the case of a family in which the mother had a patent ductus arteriosus and two of her children had a persistent truncus arteriosus confirmed by necropsy. The only somewhat similar case has been reported by Giustra and Tosti (1939)—-twin boys with true cor biloculare associated with a partial persistent truncus.

\section{CASE REPORT}

The mother, born in 1928, had been attending the cardiac clinic at Kingston General Hospital for some 
years with a diagnosis of patent ductus arteriosus, but in September, 1953, it was found that she had a systolic murmur only and it was thought that the ductus was gradually closing. In February, 1958, it was found that she was free from any murmur.

In April, 1951, the mother gave birth to a normal male infant and in July, 1953, she gave birth to another full-term male infant who died three days later. Post-mortem examination showed the presence of a persistent truncus arteriosus with two pulmonary arteries arising from the main trunk which continued as the aorta. Unfortunately there was no detailed examination and description of this heart.

In April, 1958, the mother was admitted to Hedon Road Maternity Hospital having gained over forty pounds in weight during her third pregnancy. She was found to have œedema of the ankles and sacrum although her urine and blood pressure were normal. The following month she gave birth to a post-mature female infant weighing $10 \mathrm{lb} .10 \mathrm{oz}$. A severe degree of hydramnios was present. The baby at birth was grey in colour with cold extremities and a systolic murmur was present over the præcordium. The baby's condition deteriorated and she died four days later. A post-mortem examination was carried out and the abnormalities found were confined to those of the cardiovascular system.

Examination of the heart showed a persistent truncus arteriosus measuring $1.3 \mathrm{~cm}$. in diameter, and from its posterior aspect an arterial branch, measuring $0.8 \mathrm{~cm}$. in diameter, passed behind the main trunk to enter the hilum of the right lung: a separate smaller branch, measuring $0.6 \mathrm{~cm}$. in diameter, was given off to the hilum of the left lung. These two vessels represented the arterial supply to the lungs.

The heart was somewhat enlarged, the left ventricle measuring $0.8 \mathrm{~cm}$. at its maximum thickness, and the right ventricle measuring $0.4 \mathrm{~cm}$. in thickness. Four semilunar cusps were present at the orifice of the truncus: these were distorted and on each were warty vegetations, histological examination of which showed non-specific, inflammatory, proliferative changes. The cusps were arranged as two in the anterior position and two in the posterior position. The left coronary artery arose from the left posterior sinus, and the right coronary artery from the right anterior sinus. The coronary arteries followed the normal distribution over the ventricular surface.

A moderately large ventricular septal defect was present with the common trunk over-riding the defect with some shift to the right. An atrial septal defect was also present. The right atrio-ventricular valve had two cusps only and the mitral valve had three cusps and showed severe narrowing of the orifice. A patent ductus arteriosus could not be found.

\section{EMBRyology AND SOME OTHER FeATURES}

Before the interventricular septum has become established at about the 5-mm. stage, spiral sub-endocardial thickenings, the bulbar ridges, appear in the distal part of the bulbar cordis, i.e. the truncus arteriosus, by the growth and fusion of the ridges. At about the 20-mm. stage a spiral aortico-pulmonary septum is formed which divides the bulbus cordis into the aorta and pulmonary trunk and when the interventricular foramen is finally closed, each of the arteries will be in communication with the corresponding ventricle.

Reports of truncus arteriosus persistens have appeared from time to time since Buchanan (1864) first reported the condition, and Humphreys (1932) has given the best description of the condition. Describing one new case she analysed the reported cases up to 1932, and listed the following criteria for the identification of the common arterial trunk.

(1) The primary requirement is that only one large trunk leaves the base of the heart.

(2) The arterial trunk must combine the functions of both the aorta and pulmonary trunk, giving off the coronary and systemic arteries and supplying blood to the lungs.

(3) An interventricular septal defect is always present, commonly an opening in the septum of the cardiac bulb, i.e. in the inter-aortic septum of Spitzer or the posterior part of the anterior septum of Rokitansky.

Lev and Saphir (1942) listed the details of 19 cases of truncus arteriosus that had been reported between 1932 and 1942, and also reported a case of their own. They concluded that most cases of truncus arteriosus could be explained as mild to moderate degrees of transposition where there is a combined abnormality in the bulbar ridge 3B and the septum aortico-pulmonale trunci. The abnormality in ridge 3B produces an abnormality in the absorption of the bulbus resulting in transposition. McGilpin (1950), reporting a further case, stated that cases of truncus arteriosus can be separated according to variations in the pulmonary blood supply. Vela and Abreu (1955) encountered four cases and outlined the main clinical, radiological, and electrocardiographic features.

Carlgren (1959), reviewing the children born in Gothenburg between 1941-50, found the overall incidence was 369 cases of congenital heart disease among 58,105 live-born children; these included 5 cases of truncus arteriosus, four of whom had died at the time of writing. 


\section{SUMMARY}

A case is reported which is of interest as it describes a second example of truncus arteriosus persistens occurring in two members of the same family.

The mother had a patent ductus arteriosus and two of her children had a persistent truncus arteriosus. This fact is of considerable interest as there is only one recorded instance in which two members of the same family both had this congenital lesion. The findings in these cases are in agreement with the criteria listed by Humphreys for the identification of a case of common aortopulmonary trunk.

A note has been presented on embryology in relation to the common aorto-pulmonary trunk.

I am indebted to Dr. A. J. Shillitoe and Dr. L. S. Sacker for their advice in preparing this paper.

\section{REFERENCES}

Annotation (1959). Brit. med. J., 1704.

Bertoye, P., Monnet, P., Bret, J., and Touraine, R. (1952). J. Méd. Lyon, 33, 391.

Buchanan, G. (1864). Trans. Path. Soc., London, 15, 89.

Campbell, M. (1949). Quart.J. Med., N.S., 18, 379. (1959). Brit. Heart J., 21, 65.

Carlgren, Lars-Erik (1959). 'Brit. Heart J., 21, 40.

Carleton, R. A., Abelmann, W. H., and Hancock, E. M. (1958). New England J. Med., 259, 1237.

Courter, S. R., Felson, B., and McGuire, J. (1948). Amer. J. med. Sci., 216, 501.

Ellis, R. W. B. (1933). Proc. Roy. Soc. Med., 26, 511.

Elshove, P. (1951). Ned. Tijdschr. Geneesk., 95, 2768.

Foxon, G. E. H. (1959). Brit. Heart J., 21, 51.

Giustra, F. X., and Tosti, V. G. (1939). Amer. Heart J., 17, 249.

Goldman, R., and Stern, N. S. (1952). Amer. Heart J., 44, 159.

Humphreys, Eleanor (1932). Arch. Path., 14, 671.

Kjaergaard, H. (1946). Acta med. Scand., 125, 339.

Lamy, M., Schweisguth, O., and Willk, J. (1946). Arch. franç. Pédiat., 3, 376.

Lev, M., and Saphir, O. (1942). J. Pediat., 20, 74.

Lucksch, F., and Stohr, R. (1936). Med. Klin., 32, 1631.

McGilpin, H. H. (1950). Amer. Heart J., 39, 615.

Medvei, C. V., and Rösler, H. (1932). Z. Klin. Med., 119, 527.

Murphy, D. P. (1947). Congenital Malformations. 2nd ed. Lippincott, Philadelphia and Montreal.

Uchida, Irene A., and Rowe, R. D. (1957). Amer. J. Hum. Gen., 9, 137.

Vela, J. E., and Abreu, de C. (1955). Arch. Inst. Cardiol. México, 25, 475. 